\title{
The Composition of Staphylococcus aureus in Relation to the Water Activity of the Growth Medium
}

\author{
BY J. H. B. CHRISTIAN AND JUDITH A. WALTHO \\ Commonroealth Scientific and Industrial Research Organization, \\ Division of Food Preservation, North Ryde, \\ N.S.W., Australia
}

(Received 28 October 1963)

\begin{abstract}
SUMMARY
Staphylococcus aureus organisms, grown in basal medium of water activity $\left(a_{w}\right) 0.993$ and in basal medium adjusted to several different $a_{w}$ values by addition of $\mathrm{NaCl}$, were analysed for the following components: sodium, potassium, calcium, magnesium, total amino acids, inorganic phosphate, chloride, water, DNA, RNA, protein. Cell water decreased from 1.66 to $0.83 \mathrm{~g}$. $/ \mathrm{g}$. dry weight when $a_{w}$ was decreased from 0.993 to 0.90 . Internal concentrations of solutes generally increased with decrease in $a_{w}$, potassium and phosphate concentrations being greatest at $0.92 a_{w}$ and sodium, chloride, magnesium, and amino acids at $0.90 \mathrm{a}_{\mathrm{w}}$, the lowest $a_{w}$ value studied. Increases in potassium and amino acid concentrations resulted largely from the decreased water contents of cocci grown at low $a_{w}$ values. Intracellular sodium and chloride concentrations were much lower than and proportional to the $\mathrm{NaCl}$ concentration in the medium. The predominant cell solute was potassium at $0.92 \mathrm{a}_{\mathrm{w}}$ and above, and sodium below $0.92 \mathrm{a}_{\mathrm{w}}$. The data are discussed in relation to the inhibition of bacterial growth at low $a_{w}$ values.
\end{abstract}

\section{INTRODUCTION}

Staphylococcus aureus organisms possess a high osmotic pressure, or low water activity $\left(a_{w}\right)$, when grown in normal media. Mitchell \& Moyle (1956) suggested from vapour pressure equilibration of washed cocci that their water activity was equivalent to that of 1.0 molal sucrose solution, namely about $0.98 \mathrm{a}_{\mathrm{w}}$. Christian \& Waltho (1962b) obtained a corrected freezing point of unwashed, heated staphylococci of $-3 \cdot 27^{\circ}$, corresponding to about $0.97 \mathrm{a}_{\mathrm{w}}$. Both values are appreciably lower than the $a_{w}$ values of the growth media, which were 0.999 and 0.993 , respectively. Clearly, these organisms maintain a large turgor pressure when grown in dilute media, and recent data (Christian \& Waltho, 1962a) suggest that potassium ion and amino acids may be osmotically important components of such cocci, while sodium, phosphate, and chloride are less prominent.

Staphylococci are extremely salt tolerant, growing at $a_{w}$ values down to 0.88 to 0.86 (Scott, 1953). As bacteria appear to be hypertonic to their growth medium, irrespective of its $a_{w}$ value (Christian \& Ingram, 1959), the concentrations of low molecular weight solutes in staphylococci grown at low $a_{w}$ values are of some interest. The present paper reports partial analyses of Staphylococcus aureus grown 
at $\mathrm{a}_{\mathrm{w}}$ values of 0.993 to 0.90 . Sodium, potassium, calcium, magnesium, total amino acids, inorganic phosphate, chloride, water, DNA, RNA, and protein were determined.

\section{METHODS}

Organism and groroth conditions. The test organism was Staphylococcus aureus strain 49/1974, (Scott, 1953). The basal medium was brain + heart infusion broth of $0.993 a_{w}$, adjusted where required to $a_{w}$ values of $0.97,0.94,0.92$, and 0.90 by addition of $\mathrm{NaCl}$, unless otherwise stated in the text. Scott (1953) discussed in detail the control of the $a_{w}$ value in culture media. Volumes $(600 \mathrm{ml}$.) of medium were inoculated from a $16 \mathrm{hr}$ broth culture and aerated by shaking at $30^{\circ}$ until the population reached the stationary phase. The cocci were harvested by centrifugation, washed in a $\mathrm{NaCl}$ solution isotonic with the growth medium, and suspended in $40 \mathrm{ml}$. of the $\mathrm{NaCl}$ solution. When harvested from media adjusted to $0.97 \mathrm{a}_{\mathrm{w}}$ with sucrose or to $0.92 \mathrm{a}_{\mathrm{w}}$ with $\mathrm{KCl}$, the washing was omitted and the cocci were resuspended in $40 \mathrm{ml}$. of the original supernatant fluid. Eight equal coccal pellets were obtained by centrifuging $5 \mathrm{ml}$. portions of the concentrated suspension.

Analytical methods. Interstitial space was determined by phosphate dilution and was used to correct water content, dry weight, and chemical analyses for contributions of the contaminating interstitial solution. These techniques were described in detail by Christian \& Waltho (1962a), as were methods for extraction and analysis of sodium, potassium, total amino acids (as ninhydrin-positive substances), inorganic phosphate, and chloride. In studies of dextran-impermeable water, dextran was determined by the anthrone method (Scott \& Melvin, 1953). Additional analyses performed were for magnesium and calcium by atomic absorption spectroscopy and protein by the method of Lowry, Rosebrough, Farr \& Randall (1951). Deoxyribonucleic acid (DNA) and ribonucleic acid (RNA) were extracted by the method of Burton (1956) and determined with the diphenylamine and orcinol reagents, respectively. The nitrogen content of trichloroacetic acid-extracted cocci was determined by the Kjeldahl procedure. All analyses were performed in duplicate.

The water sorption isotherm at $25^{\circ}$ of heated cocci was obtained by the isopeistic technique of Robinson \& Sinclair (1934). The coccal preparations were equilibrated with saturated solutions of potassium dichromate, potassium dihydrogen phosphate, potassium nitrate, and barium chloride. The $a_{w}$ value of saturated potassium dihydrogen phosphate was found in this laboratory to be 0.952 at $25^{\circ}$; those of the other solutions were given by Stokes \& Robinson (1949).

\section{RESULTS}

\section{Cell water content}

When phosphate dilution is used to determine the extent of interstitial space in a centrifuged pellet, it is assumed that the volume found represents that space which is rapidly and passively permeated by other solutes of low molecular weight. In preliminary experiments with $0.02 \mathrm{M}-\mathrm{Na}, \mathrm{K}$ phosphate buffer and water-washed cocci, the volumes accessible to sodium and potassium were much greater than that accessible to phosphate. It appeared that surface charges or differences in perme- 
ability were affecting the distribution of these ions. However, the values for the three ions were not appreciably different with $0.993 \mathrm{a}_{\mathrm{w}}$ buffer (about $0.2 \mathrm{M}$ ). This concentration of phosphate (with the addition, where necessary, of $\mathrm{NaCl}$ to give the solution the same $a_{w}$ value as the growth medium), was used routinely in the determination of interstitial volume.

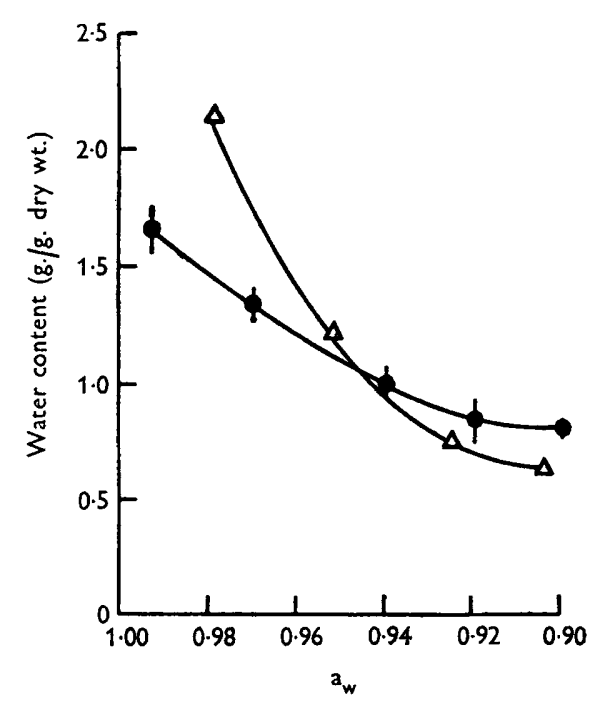

Fig. 1

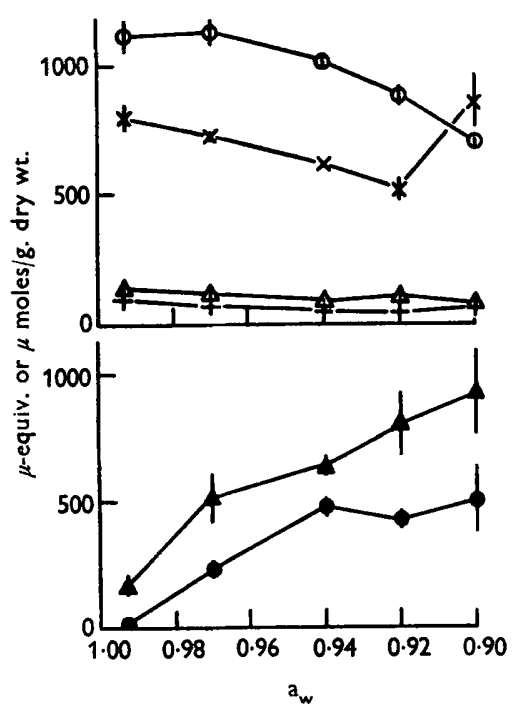

Fig. 2

Fig. 1. Water content of Staphylococcus aureus in relation to the external $a_{w}$ level. 0 , Cells grown in broth adjusted with $\mathrm{NaCl}$ to $a_{w}$ levels from 0.993 to 0.900 . Standard errors of mean values are shown by vertical lines. $\Delta$, Cells grown at $0.998 a_{w}$, heated and equilibrated to four $a_{w}$ levels.

Fig. 2. Amounts of six solutes in cells of Staphylococcus aureus grown in broth adjusted with $\mathrm{NaCl}$ to $\mathrm{a}_{w}$ levels from 0.993 to 0.90 . $\triangle$, Sodium; $O$, potassium; + , magnesium; $\times$, total amino acids; $\Delta$, inorganic phosphate; $O$, chloride. Standard errors of mean values are shown by vertical lines. Sodium, potassium and chloride are expressed as $\mu$-equivalents, the remainder as $\mu$ moles.

The water content of staphylococci as a function of the $a_{w}$ value in the medium is shown in Fig. 1. Reduction of $\mathrm{a}_{\mathrm{w}}$ from 0.993 to 0.90 by addition of $\mathrm{NaCl}$ decreased cell water by $50 \%$ from 1.66 to $0.83 \mathrm{~g}$. $/ \mathrm{g}$. dry weight. This change in cell water was related to $\mathrm{a}_{\mathrm{w}}$ value, not to $\mathrm{NaCl}$ concentration, since similar values were obtained with sucrose $\left(0.97 \mathrm{a}_{\mathrm{w}}\right)$ and $\mathrm{KCl}\left(0.92 \mathrm{a}_{\mathrm{w}}\right)$ additions (Table 1). Increasing the $\mathrm{a}_{\mathrm{w}}$ value to 0.998 by dilution of the medium with water increased the cell water content to $2 \cdot 44 \mathrm{~g}$. $/ \mathrm{g}$. dry weight (Table 3).

For comparison, Fig. 1 includes the water sorption isotherm for staphylococci grown in basal medium $\left(0.993 a_{w}\right)$, washed in water and heated to destroy the osmotic barrier. At high $a_{w}$ values, whole cocci held much less water than heated cocci, suggesting that the $a_{w}$ within the whole coccus was substantially below that of the growth medium. The situation was reversed at low $a_{w}$ values, and could be explained if cocci grown at 0.92 and $0.90 \mathrm{a}_{\mathrm{w}}$ had higher solute contents than the heated preparation, which was grown at $0.993 \mathrm{a}_{\mathrm{w}}$. 
Mitchell \& Moyle (1956) found the difference between phosphate-impermeable and dextran-impermeable water of staphylococci to be $0.18 \mathrm{ml} . / \mathrm{g}$. dry wt. This was about $12 \%$ greater than the phosphate-impermeable or intracellular water, and was interpreted as the water content of the cell wall. In the present studies, similar experiments indicated that the water in the cell wall was $11 \%$ greater than the intracellular water after growth at $0.993 a_{w}$, and $14.5 \%$ greater after growth at $0.90 \mathrm{a}_{\mathrm{w}}$.

\section{Internal solutes of Staphylococcus aureus}

The sodium, potassium, magnesium, amino acid, chloride, and inorganic phosphate contents of cocci grown at various $\mathrm{a}_{\mathrm{w}}$ values in $\mathrm{NaCl}$-adjusted media are shown in Fig. 2. Values are expressed on the basis of cell dry wt. Sodium and chloride contents increased with decrease of $a_{w}$ value to 0.90 , probably reflecting the increased $\mathrm{NaCl}$ concentration in the medium. The other components decreased between 0.993 and $0.90 a_{w}$, with the exception of the amino acid pool, which increased steeply below $0.92 \mathrm{a}_{\mathrm{w}}$. Assuming an average molecular wt. of 120 for the amino acids, the solutes of Fig. 2 represent about $16 \%$ of the dry wt. of cocci grown at $0.993 a_{w}$ and $18 \%$ when grown at $0.90 a_{w}$.

Figure 3 presents the apparent intracellular concentrations of these solutes, obtained by expressing the values of Fig. 2 in terms of the cell water contents of Fig. 1, and assuming that all of these ions and molecules were in free solution within the cell. The concentrations are molal, i.e. moles of solute $/ \mathrm{kg}$. cell water. On this basis, intracellular sodium and chloride concentrations increased approximately linearly down to $0.90 \mathrm{a}_{\mathrm{w}}$. The mean ratios of internal to external concentration were 0.41 for sodium and 0.23 for chloride. Increases occurred in potassium, amino acids, and phosphate concentrations as the $a_{w}$ value was decreased to 0.92 . The ratios of these three concentrations were 100:71:12 at $0.993 \mathrm{a}_{\mathrm{w}}$ and 100:60:11 at $0.92 a_{w}$. Decreasing the $a_{w}$ value to 0.90 decreased the potassium and phosphate concentrations, while the amino acids increased by over $70 \%$. As the amounts of these three constituents in the media were constant at all $a_{w}$ values, the changes observed in intracellular concentrations were due to either the value of $a_{w}$ or the concentration of $\mathrm{NaCl}$ in the growth media. The calcium content of cocci, although not precisely determined, was less than $6 \mu$-equiv./g. Cocci were much richer in magnesium, which occurred in highest concentration at $0.90 \mathrm{a}_{\mathrm{w}}$ and in lowest at $0.92 a_{w}$. Thus, the trend in magnesium concentration on decreasing the value of $a_{w}$ was broadly the reverse of that for potassium and phosphate.

\section{The effect on cell composition of the solute used to control $a_{w}$ level}

In experiments described above, $a_{w}$ was adjusted to desired values with $\mathrm{NaCl}$ only. Thus, resulting changes in composition could be ascribed equally to the $\mathrm{NaCl}$ concentration as to the $a_{w}$ value. Table 1 provides comparisons of water content and sodium and potassium concentrations in staphylococci grown at $a_{w}$ values controlled by the addition of various solutes. Clearly, water content was a function of $a_{w}$ value, not of the solute used. Cell sodium remained approximately the same at all three $a_{w}$ values when $\mathrm{NaCl}$ had not been added to the medium. Hence it depended primarily on the external salt concentration, not the $a_{w}$ value. In contrast, cell potassium was influenced both by the $a_{w}$ value and by high concentrations of $\mathrm{KCl}$ in the medium. 
Table 1. Water, sodium and potassium contents of Staphylococcus aureus grown in media* adjusted to several $a_{w}$ with $\mathrm{NaCl}, \mathrm{KCl}$ or sucrose

\begin{tabular}{|c|c|c|c|c|}
\hline$\stackrel{\mathbf{a}_{\mathrm{w}}}{\text { value }}$ & $\begin{array}{l}\text { Adjusting } \\
\text { solute }\end{array}$ & $\begin{array}{c}\text { Cell water } \\
\text { (g./g. dry wt.) }\end{array}$ & $\begin{array}{l}\text { Sodium } \\
\text { (m molal) }\end{array}$ & $\begin{array}{r}\text { Potassium } \\
(\mathrm{m} \text { molal })\end{array}$ \\
\hline 0.993 & Nil* & 1.66 & 100 & 671 \\
\hline 0.97 & $\mathrm{NaCl}$ & $1 \cdot 35$ & 382 & 837 \\
\hline 0.97 & Sucrose & 1.37 & 84 & 841 \\
\hline 0.92 & $\mathrm{NaCl}$ & $0 \cdot 86$ & 930 & 1020 \\
\hline 0.92 & KCl & 0.90 & 78 & 1922 \\
\hline
\end{tabular}

* Basal medium was brain + heart infusion broth.

Influence of the basal medium on concentrations of potassium and amino acids in staphylococci

The ratio of potassium to amino acids was essentially constant in cocci grown at $0.92 a_{w}$ and above (Fig. 3). The concentrations of these solutes in the growth media were also constant. To determine the importance of external concentrations of potassium and amino acids in controlling internal concentrations, cocci were analysed after growth at $\mathbf{0 . 9 9 3} \mathrm{a}_{\mathrm{w}}$ in media whose potassium : amino acid ratio was varied almost 20 -fold (Table 2). Very small changes in cell composition resulted from these treatments. Thus at these values, external concentrations of potassium and amino acids did not influence appreciably the amounts accumulated by the cocci. This result contrasts with the effect of very high external potassium concentrations discussed above.

Table 2. Effect of potassium and amino acid concentrations in the groroth medium on the composition of Staphylococcus aureus grown at $0.993 a_{w}$

\begin{tabular}{|c|c|c|c|c|}
\hline & \multicolumn{4}{|c|}{ Medium* } \\
\hline & $\mathbf{A}$ & $\mathbf{B}$ & $\mathbf{C}$ & $\mathbf{D}$ \\
\hline \multicolumn{5}{|l|}{ In medium } \\
\hline Potassium (mM) & $23 \cdot 8$ & $6 \cdot 0$ & $26 \cdot 8$ & 6.5 \\
\hline Amino acids (mM) & $27 \cdot 2$ & $6 \cdot 8$ & 6.8 & $\mathbf{8 1 \cdot 3}$ \\
\hline Potassium : amino acids & $0 \cdot 87$ & 0.87 & 3.94 & 0.21 \\
\hline \multicolumn{5}{|l|}{ In cells } \\
\hline Potassium ( $\mu$-equiv./g. dry wt.) & 1120 & 1150 & 1240 & 1020 \\
\hline Amino acids $(\mu \mathrm{mole} / \mathrm{g}$. dry wt.) & 588 & 582 & 564 & 508 \\
\hline Potassium : amino acids & 1.91 & 1.91 & 2.19 & 2.04 \\
\hline
\end{tabular}

\section{Composition of staphylococci growon in dilute media}

As most common laboratory media have $a_{w}$ values well above that of brain + heart infusion broth $\left(0.993 \mathrm{a}_{\mathrm{w}}\right)$, water, sodium, and potassium contents were determined for comparison in cocci harvested from media of 0.998 and $0.9965 \mathrm{a}_{\mathrm{w}}$. These were obtained by diluting the basal medium to one-quarter and one-half strength, respectively. The results are compared in Table 3 with those obtained with 0.993 $a_{w}$ medium. Increase in $a_{w}$ value resulted in an increase in cell water and a decrease 
in cell solute concentrations. However, in spite of the marked fall in sodium and potassium content of the medium as it was diluted to one-quarter strength, both sodium and potassium/g. dry wt. cocci remained relatively constant.
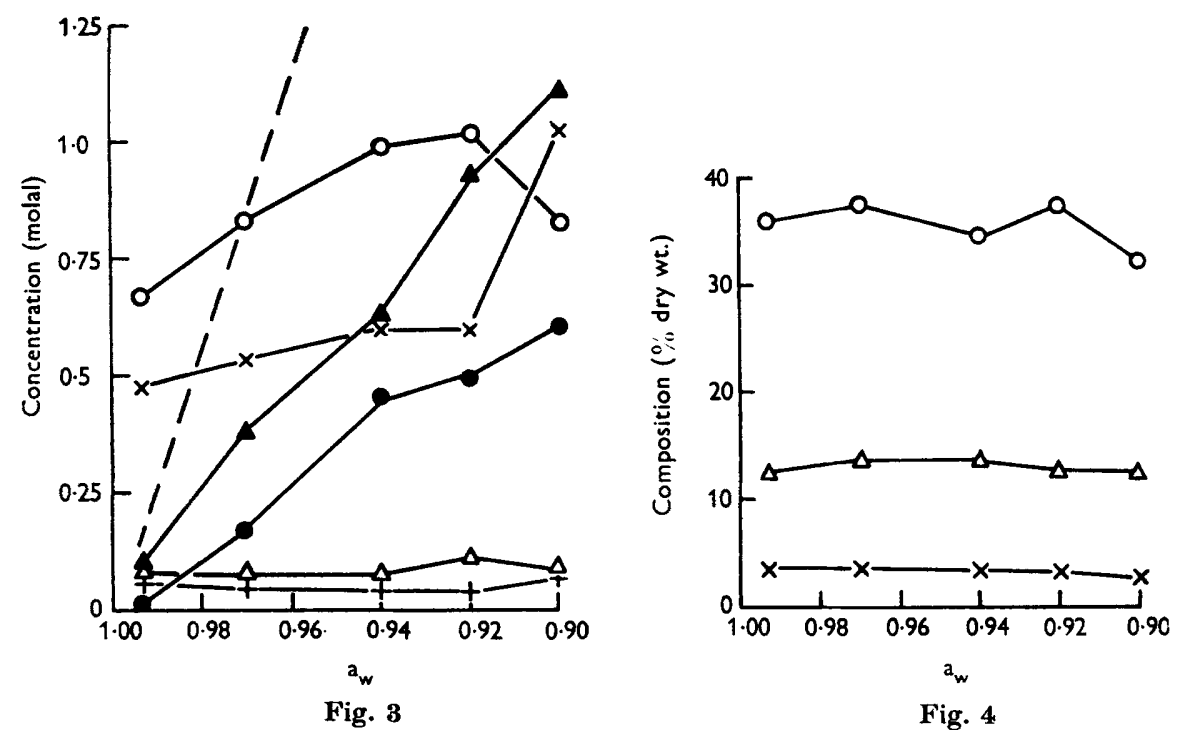

Fig. 3. Concentrations of six solutes in cells of Staphlococcus aureus grown in broth adjusted with $\mathrm{NaCl}$ to $\mathrm{a}_{\mathrm{w}}$ levels from 0.993 to 0.90 . $\Delta$, Sodium; $O$, potassium; + , magnesium; $x$, total amino acids; $\triangle$, inorganic phosphate; $\theta$, chloride. The $\mathrm{NaCl}$ concentration in the medium is shown by broken line.

Fig. 4. Protein, DNA, and RNA content of cells of Staphylococcus aureus grown in broth adjusted with $\mathrm{NaCl}$ to a levels from 0.993 to 0.90. O, Protein; $\times$, DNA; $\triangle$, RNA.

Table 3. Water, sodium and potassium contents of Staphylococcus aureus grozon in media of high $a_{w}$ value

\begin{tabular}{|c|c|c|c|c|c|c|}
\hline \multirow{2}{*}{$\begin{array}{l}\text { Dilution } \\
\text { of basal } \\
\text { medium* } \\
\text { with water }\end{array}$} & \multirow[b]{2}{*}{$\begin{array}{c}\mathbf{a}_{\mathbf{w}} \\
\text { value }\end{array}$} & \multirow{2}{*}{$\begin{array}{c}\text { Cell } \\
\text { water } \\
\text { (g./g. dry } \\
\text { wt.) }\end{array}$} & \multicolumn{2}{|c|}{ Sodium } & \multicolumn{2}{|c|}{ Potassium } \\
\hline & & & (m molal) & $\begin{array}{l}\text { ( } \mu \text {-equiv./g. } \\
\text { dry wt.) }\end{array}$ & (m molal) & $\begin{array}{l}\text { ( } \mu \text {-equiv./g. } \\
\text { dry wt.) }\end{array}$ \\
\hline Nil & $0 \cdot 993$ & 1.66 & 100 & 166 & 671 & 1116 \\
\hline $1: 1$ & 0.9965 & 1.92 & 71 & 137 & 553 & 1060 \\
\hline $1: 3$ & 0.998 & $2 \cdot 44$ & 62 & 151 & 426 & 1040 \\
\hline
\end{tabular}

* Basal medium was brain + heart infusion broth.

\section{Some macromolecular constituents}

The steep increase in the amino acid pool below $0.92 a_{w}$ (Fig. 3) suggested that incorporation of amino acids into protein might be inhibited under these conditions. Protein contents of cocci grown at the various $a_{w}$ values were determined and are shown, together with the DNA and RNA values, in Fig. 4. The average protein content at the five values of $a_{w}$ was $35.3 \%$ of the dry wt. The most marked change was a $14 \%$ decrease in protein between 0.92 and $0.90 a_{w}$. DNA averaged only $3.13 \%$ over the five $a_{w}$ values, and, like protein, decreased by $15 \%$ below $0.92 a_{w}$. 
RNA contents were similar throughout, averaging $12.9 \%$ of coccal dry wt. At all five $a_{w}$ values, the total nitrogen content (calculated) of protein constituents was equal to about $64 \%$ of the trichloroacetic acid-insoluble nitrogen as determined by Kjeldahl digestion and titration.

\section{DISCUSSION}

The experiments of Mitchell \& Moyle (1956) suggested that the $18 \%$ of the dry weight of staphylococci which could be extracted with trichloroacetic acid represented the low molecular weight solutes responsible for the cell osmotic pressure; $18 \%$ is probably a slight underestimate since some solutes (e.g. sodium ions; Christian, 1962), would be removed by the preliminary water washing. The sum of the six solutes studied here was equivalent to $16-18 \%$ of the coccal dry weight, and presumably these form the bulk of osmotically important solutes in the organisms. In view of the relatively low intracellular chloride and phosphate contents, high concentrations of other anions must be present to effect an ionic balance. Staphylococcus aureus organisms grown at $0.993 \mathrm{a}_{\mathrm{w}}$ contain sufficient fixed anions (not removed by butanol treatment and water washing) to balance about one-quarter of their potassium (Christian, 1962). Preliminary experiments indicate that other important anions include organic acids and the dicarboxylic amino acids, glutamic and aspartic acid.

It is tempting to calculate from the analytical data the intracellular $a_{w}$ of cocci grown at the various $a_{w}$ values. However, this will not be fruitful until the nature of the various anions and amino acids is known. Meanwhile, an estimate of the $a_{w}$ value in cocci grown in basal medium may be obtained from the data of Fig. 1. Whole cocci contained $1.66 \mathrm{~g}$. water $/ \mathrm{g}$. dry wt. Similar cocci, after heat treatment, contained this amount of water when in equilibrium with a solution of $0.967 a_{w}$. This is close to the cell $a_{w}$ value deduced from cryoscopic experiments with similar preparations (Christian \& Waltho, 1962b). The curves of Fig. 1 converge and intersect at low $a_{w}$ values probably because of the much lower sodium content of heat-treated cocci, which were grown at $0.993 a_{w}$ and washed in water. At $0.90 a_{w}$, the whole cocci contained about $1 \cdot 1$ molal sodium, which was absent from the heated preparation. Addition of this concentration of a sodium salt similar to $\mathrm{NaCl}$ would increase the equilibrium water content of heated cocci at $0.90 \mathrm{a}_{\mathrm{w}}$ by about $0.25 \mathrm{~g}$. $/ \mathrm{g}$. dry wt. This would slightly more than compensate for the difference between the curves near $0.90 a_{w}$. This indicates that cocci grown at low $a_{w}$ values maintain a small turgor pressure, as predicted by the cryoscopic determinations of Christian \& Ingram (1959).

Of the solutes examined, only sodium and chloride ions were found at lower concentrations in the cocci than in the medium. The only analogous data for bacteria are those of Schultz \& Solomon (1961) and Schultz, Wilson \& Epstein (1962), who examined exponential-phase organisms of Escherichia coli grown in a medium containing $\mathrm{NaCl}$ at concentrations below $0.15 \mathrm{M}$. Intracellular sodium and chloride concentrations were less than and approximately proportional to the external $\mathrm{NaCl}$ concentrations. The ratios were about 0.5 and $0 \cdot 3$, respectively, which are similar to those found in the present study.

The low apparent intracellular concentrations of sodium and chloride might be explained if these ions were confined to compartments in which their concentrations 
were the same as in the medium. While staphylococci have an appreciable requirement for potassium (Shooter \& Wyatt, 1956), it has been reported that they do not require sodium (Shooter \& Wyatt, 1957). Also, sodium is readily removed from staphylococci by treatments which leave the potassium content unaltered (Christian, 1962). Thus sodium could reside in a non-specific compartment. In cocci grown at $0.92 \mathrm{a}_{\mathrm{w}}$, the sums of intracellular sodium and potassium were very similar, whether the medium was adjusted with $\mathrm{NaCl}$ or $\mathrm{KCl}$. Presumably, in cocci grown in $\mathrm{KCl}$ the excess potassium ions would be in the non-specific compartment. This would divide intracellular potassium into two pools, one non-specific and the other specifically accumulated. There are insufficient data here to test the compartment hypothesis, but this system clearly offers opportunities for further study. However, it should be borne in mind that the apparent sodium and chloride contents of cocci depend upon the position of boundaries determined by studies of phosphate impermeability. Thus they might merely reflect a gradation of sodium, chloride, and phosphate penetration that is governed by ionic properties of the cell surface.

In contrast to the low chloride content of staphylococci grown in high $\mathrm{NaCl}$ concentrations are the very high values of chloride found in extreme halophiles (Christian \& Waltho, 1962a). It may be relevant that, relative to cell potassium content, the latter strains accumulated very small amino acid pools.

Potassium concentrations in staphylococci appeared to be a function of the $a_{w}$ value whenever the external sodium:potassium ratio was high. Neither large variations in the external potassium:amino acids ratio nor decrease of $a_{w}$ value to 0.92 by addition of $\mathrm{NaCl}$ altered appreciably the potassium:amino acid ratio within the cocci. Hence the coccal amino acid concentration was also related to the $a_{w}$ value, and the mechanisms which control the accumulation of potassium and amino acids appeared to be linked in some way. The reciprocal changes in concentrations of these solutes observed below $0.92 a_{w}$ were therefore evidence of a marked disturbance of metabolism.

Between 0.92 and $0.90 \mathrm{a}_{\mathrm{w}}$ the amino acid pool increased by $336 \mu$ moles/g. dry wt., while protein decreased by $52 \mathrm{mg}$./g. These changes would be equivalent if the mean molecular weight of the amino acids concerned were 155. This value is of the correct order, suggesting that most of the sharp increase in the amino acid pool resulted from decreased protein synthesis. A low $a_{w}$ value might inhibit amino acid incorporation directly. However, since decrease of $a_{w}$ value from 0.993 to 0.90 inhibits respiration by more than $\mathbf{8 0} \%$ (unpublished data), it is more likely that low respiration rates limit the energy available for protein synthesis. Decreased respiration would also decrease the accumulation of potassium and inorganic phosphate. Influx of amino acids may be decreased also, but a much lower rate of utilization could result in a net increase in pool size. It seems probable that further investigations in this region $\left(0.92-0.90 a_{w}\right)$ would reveal which steps in metabolism are primarily affected by restriction of the $a_{w}$ value. 


\section{REFERENCES}

Bunton, K. (1956). A study of the conditions and mechanism of the diphenylamine reaction for the colorimetric estimation of deoxyribonucleic acid. Biochem. J. 62, 315 .

Christian, J. H. B. (1962). The effects of washing treatments on the composition of Staphylococcus aureus. Aust. J. biol. Sci. 15, 324.

Christian, J. H. B. \& Ingram, M. (1959). The freezing points of bacterial cells in relation to halophilism. J. gen. Microbiol. 20, 27.

Christian, J. H. B. \& Waltho, J. A. $(\mathbf{1 9 6 2} a)$. Solute concentrations within cells of halophilic and non-halophilic bacteria. Biochim. biophys. Acta, 65, 506.

Christian, J. H. B. \& Waltho, J. A. (1962b). The water relations of staphylococci and micrococci. J. appl. Bact. $25,369$.

Lowry, O. H., Rosebrough, N. J., Farr, A. L. \& Randall, R. J. (1951). Protein measurement with the Folin phenol reagent. J. biol. Chem. 193, 265.

Mrtchell, P. \& MoYLe, J. (1956). Osmotic structure and function in bacteria. Symp. Soc. gen. Microbiol. 6, 150.

Robinson, R. A. \& Sinclair, D. A. (1934). The activity coefficients of the alkali chlorides and of lithium iodide in aqueous solution from vapour pressure measurements. J. Amer. Chem. Soc. 56, 1830.

Schultz, S. G. \& Solomon, A. K. (1961). Cation transport in Escherichia coli. I. Intracellular $\mathrm{Na}$ and $\mathrm{K}$ concentrations and net cation movement. J. gen. Physiol. 45, 355.

Schultz, S. G., Wilson, N. L. \& Epstern, W. (1962). Cation transport in Escherichia coli. II. Intracellular chloride concentration. J. gen. Physiol. 46, 159.

Scotт, T. A. \& Melvin, E. H. (1953). Determination of dextran with anthrone. Analyt. Chem. 25, 1656.

Scotr, W. J. (1953). Water relations of Staphylococcus aureus at $30^{\circ}$ C. Aust. J. biol. Sci. 6, 549 .

Shooter, R. A. \& WyatT, H. V. (1956). Mineral requirements for growth of Staphylococcus pyogenes. Effect of potassium ions. Brit. J. exp. Path. 37, 311.

Shooter, R. A. \& WyATT, H. V. (1957). Mineral requirements for growth of Staphylococcus pyogenes. Effect of sodium ions. Brit. J. exp. Path. 38, 473.

Stokes, R. H. \& Robinson, R. A. (1949). Standard solutions for humidity control at $25^{\circ}$ C. Industr. Engng Chem. (Industr.), 41, 2013. 